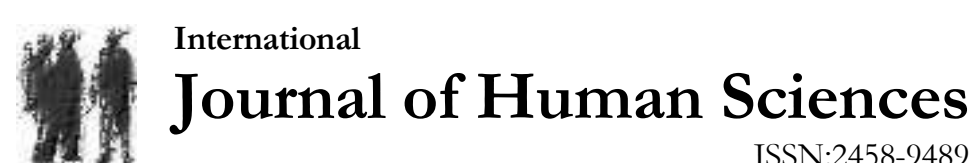

Volume 16 Issue 3 Year: 2019

\section{Examining the Gathering of Nations Powwow and a NCCA Division I basketball game}

\author{
Steven Aicinena ${ }^{1}$ \\ Sebahattin Ziyanak ${ }^{2}$
}

\begin{abstract}
Powwows are ceremonial gatherings of North America's indigenous peoples that deliver ritual focus, solidarity, collective identity, cohesion, and cultural persistence through song, dance, and social interaction. Powwows underwent significant transformations after indigenous peoples' contact with European colonialists. The Gathering of Nations Powwow is a large intertribal contest powwow (LICP) that attracts over 3,500 dancers who compete for prize money in front of more than 15,000 spectators. This paper examines the construction of a large intertribal contest powwow and an NCAA Division I basketball game. The purpose of this study is to determine in what ways the structure of the Gathering of Nations Powwow and a New Mexico Lobo (NCAA Division I Institution) basketball game are similar and different in promotional and staging activities. This study focused on two questions "Are both LICPs and NCAA Division I basketball games rightfully considered spectacles?" And, "If LICPs are, indeed, spectacles, to what extent do they share the structural characteristics of sports spectacles such as NCAA Division I basketball games?" The participant observation method is utilized to make comparisons between the two events. All field ethnographic observations were conducted during the 2018 Gathering of Nations Powwow and a University of New Mexico men's basketball game held during the 2018-19 season. We determined that the Gathering of Nations Powwow is a spectacle and that it is highly similar to an NCAA Division I basketball game in terms of its structure.
\end{abstract}

Keywords: Gathering of Nations Powwow; large intertribal contest powwows; Native Americans; powwows; NCAA basketball; Pan-Indianism; spectacle; spectator sport

\section{Introduction}

Powwows are traditional ceremonial gatherings that function to preserve the cultural heritage of North America's indigenous peoples by providing ritual focus, solidarity, cohesion, and cultural persistence through song, dance and social interaction (Dufrene, 1990; Kracht, 1994). The origination of the term powwow is inexact, but early forms of the term referred to the holy people and religious activities of Native American groups. Shepard (1648) described Pawwow as native holy leaders and

\footnotetext{
${ }^{1}$ Professor, University of Texas Permian Basin, College of Arts and Sciences, Kinesiology, aicinena s@utpb.edu

${ }^{2}$ Assistant Professor, University of Texas Permian Basin, College of Arts and Sciences, Sociology, ziyanak s@utpb.edu
} 

game. Journal of Human Sciences, 16(3), 875-884. doi:10.14687/jhs.v16i3.5742

observed that Pawwowing encompassed their religious activities. In 1660, pawe: wa referred to a magical ceremony among North American Indians (Harper, 2018). Medicine men and spiritual leaders of New England's Algonquian tribe were known as the Puau (Cogley, 1995). "Powwow" was commonly used as a label to describe gatherings or meetings of Native Americans by 1812 (Harper, 2018).

Thousands of powwows are conducted by Native Americans throughout North America each year (Eschbach \& Applbaum, 2000). They share many similarities; however, they are also impacted by local culture and history (Fowler, 2005). As noted by seventeenth-century missionary, Paul Le Jeune (Eisen, 1978),

There are many tribes in these countries who agree in a number of things and differ in many others; so that when it is said that certain practices are common to the Savages, it may be true of one tribe and not true of another (p. 60).

Accordingly, differences can be observed in powwows conducted by various tribes throughout the United States. Examples include differences in the styles of dance, song, and ceremonial activities.

\section{Literature Review}

Contest powwows conducted in public settings typically share common characteristics. Dancers don colorful and intricately designed regalia and move to the cadence of drums or gourds while culturally relevant songs are sung in vocables and native languages. Regalia often reflect tribal affiliations of dancers but can also include logos of NFL or college athletic teams, or those of cartoon characters (DesJarliat, 1997). As was true in ancient times, warriors, elders, the ill, and the memory of the deceased are honored (Abdul-Karim, 2015; Barker, 2010). In the traditional spirit of community and generosity, giveaways are conducted (McClaskey, 2009). Emcees retell stories of Native American history, recount tribal legends, and share Indian humor (Barron, 2009). Indigenous languages are often spoken at contest powwows, and traditional foods are shared or sold in vendor areas where traditional arts and crafts are hawked (Hoefnagels, 2007). Dancers compete for cash prizes and awards. Contest powwows assist in the creation and maintenance of community as family, friends, and visitors come together to participate in powwow activities (Ellis, Lassiter, \& Dunham, 2005; McDermott, 2012; Metsker, 2013).

There is no comparison in the previous literature between activities common to both the contest powwow and intercollegiate athletic events. Derek Mathews, founder of the Gathering of Nations stated that he modeled the Gathering of Nation Powwow after commercialized sporting events. To better understand the evolution of powwow, this study is essential in examining the extent of the similarities and differences of the contest powwows and intercollegiate athletic events. In addition, the second goal of this study is to determine whether or not large intertribal contest powwows, when compared to NCAA Division I basketball games, can rightfully be classified as spectacles.

\subsection{LICPs and NCAA Basketball Games as Spectacles}

A spectacle is a, "large-scale, extravagant cultural production that is replete with striking visual imagery and dramatic action that is watched by a mass audience" (Manning, 1992, p. 291). Both LICPs and NCAA Division I basketball games are large-scale events. Media specialists, designers, printers, ticket sellers, traffic attendants, concessionaires, announcers, isle attendants, security staff, administrators and others are required to plan, promote and conduct each aspect of the events, in which thousands of spectators attend. 

game. Journal of Human Sciences, 16(3), 875-884. doi:10.14687/ihs.v16i3.5742

The extravagance of each event is reflected by the production quality of activities associated with the events and the cost of attendance. Each event is not limited to the facilities in which they are held. As a result, significant amount of money both are invested and generated. Every aspect of the events is controlled, timed, and choreographed with the goal of providing optimal customer experiences.

Striking displays of cultural imagery can be observed at both the contest powwow and basketball game. During powwow grand entries as many as 3,500 Native Americans in full regalia dance together on the arena floor to the sounds of beating drums and wailing voices. Likewise, basketball games include similar display as athletes, cheerleaders, dance squads and fans wear the colors of their team and don items branded with university-approved logos. At times, it seems the arena is awash with the color of the home team. In unison, spectators sing fight songs and make hand gestures associated with their institution or mascot. Athletic department flags adorn the facility and are carried aloft by spirit squad members.

Both the contest powwow and basketball game provide dramatic action in the form of specific individual performances. Competition also creates tension and drama, be it during a final dance off or a shot released as a period ends.

The contest powwow and basketball involve masses of spectators. Regular season basketball games attract crowds as large as 23,461 for a Division I school. Member institutions of the division's top ten conference attendance leaders averaged 7,406 fans per basketball contest in 2017 - 2018 season (NCAA 2018). Games are often broadcast on television and viewed by additional masses of people. Contest powwows, such as the Gathering of Nations (GON), can attract crowds of more than 15,000 spectators for a single session (Gathering of Nations, 2018a). The event is also streamed electronically to a worldwide audience. It was announced during the third session of the 2018 GON that 1.8 million individuals in 68 countries had viewed the powwow on powwows.com. Well-attended contest powwows and basketball games are rightly considered spectacles. Both are large-scale, extravagant cultural productions replete with striking visual imagery and dramatic action that are watched by mass audiences.

Some Native American traditionalists believe that large intertribal contest powwows are inauthentic representations of indigenous culture. Indeed, the GON, and contest powwows like it are commercialized and differ from traditional powwows in many ways. GON organizer, Derek Mathews, has been accused of being, "a non-Indian profiteer who exploits traditional customs" (Dell'Angela, 2003, p. 5). However, Mathews has made it clear that the GON was never meant to be a traditional gathering. Though it is a celebration of Native American culture, the GON's structure and staging were modeled after that of athletic events. In what specific ways might the GON Powwow reflect an athletic spectacle?

\section{Methods}

In this study, we employ participant observation as a tool to conduct qualitative research. Our study about the similarities and differences between the GON Powwow and the University of New Mexico (UNM) Lobo men's basketball game was field based and ethnographic. This method provides the researchers stronger validity with objective and accurate information to reduce limitation including potential bias of researchers and generalizability of research findings.

We sought to gain a better perspective on the powwow's past and current meaning and surroundings by exploring similarities and differences between a large intertribal contest powwow and a commercialized NCAA Division I basketball game. In order to accomplish our goal, the first author attended a Gathering of Nations Powwow and a University of New Mexico men's basketball game as a paying customer. 

game. Journal of Human Sciences, 16(3), 875-884. doi:10.14687/jhs.v16i3.5742

Observations from the field were prudently verified and assisted as a foundation for assembling our findings. Field notes were taken during each event concerning twelve specific factors that were compared. Photographs were taken at the powwow to assist in comparisons. This method also helps the researchers analyze how findings are structured and ordered and how Native American indigenous people are interconnected. This tool also is very useful for the researchers to examine their cultural identity and parameters (Ziyanak, 2014).

Field observations concerning the GON Powwow were made April $27^{\text {th }}$ and $28^{\text {th }}, 2018$ on the New Mexico State Fairgrounds located in Albuquerque, New Mexico and inside Tingley Coliseum which is located on the fairgrounds. Eleven hours were spent in observation each day from 11:00 am until 10:00 pm.

Field observations concerning a Lobo basketball game were made by attending a home game against Colorado State University on March 2, 2018. Observation of the Lobo basketball game involved approximately three and a half hours $(6: 50 \mathrm{pm}-10: 18 \mathrm{pm})$ from the first author's arrival at the parking lot until departure from the arena. The game was held at the University of New Mexico's arena located in Albuquerque, New Mexico. The arena is locally referred to as the "Pit".

After establishing a list of factors important in the staging and promotion of athletic events, the focus of the current study was to determine if all factors were common to both the powwow and basketball game, which ones might be absent, and how the nature of the factors may have differed in the two settings. For example, if concessions are a component of a basketball event, are they present in the powwow setting? If so, how do the concessions provided differ in number and type?

\section{Findings and Results}

Below, we presented the similarities and differences in the twelve factors involved in promoting and staging the powwow and the basketball game.

\subsection{Advertising}

As a means of advertising their events, both UNM and the GON had a presence on the "Visit Albuquerque" (City of Albuquerque) website. The GON was also advertised on the "New Mexico True" (New Mexico Tourism Department) website. If looking for something to do in Albuquerque, information about the powwow and Lobo basketball could be seen by individuals interested in attending a spectacle.

\subsection{Social media}

The GON Powwow and UNM Athletics supported websites that provided information concerning dates and times of events, ticket purchasing opportunities, and information pertinent to each event. Each entity also maintained social media sites including Facebook and Twitter pages. They were used to advertise events and highlight specific stories associated with each organization. No significant differences were noted in the area of advertising on the social media sites.

Both the GON and UNM provided radio and video broadcasts. The GON Powwow was not broadcast live on television networks but was streamed live each year on livestream.com and was made available live and on demand at Powwows.com (Gathering of Nations, 2018a). On Saturday afternoon of the 2018 powwow, it was announced that as of $3: 45$ pm, 1.8 million viewers from 68 countries viewed the powwow live over internet feeds. In 2018-19, Lobo basketball games were broadcast live on various networks including the Mountain West, AT\&T SportsNet, Fox Sports, ESPN2, ESPNU, CBS Sports, and others (golobos.com, 2019). 

game. Journal of Human Sciences, 16(3), 875-884. doi:10.14687/jhs.v16i3.5742

Gathering of Nations Radio broadcasted the powwow over the internet (Gathering of Nations, 2018a). Lobo basketball radio broadcasts were transmitted over the Lobo Radio Network consisting of nineteen stations throughout New Mexico, Colorado and Arizona (golobos.com, 2018). The fact that the GON does not broadcast over traditional radio and television networks was a notable difference between the two events.

\subsection{Tickets}

Both the GON powwow and the UNM Athletic Department charged admission to their events, and tickets were available for purchase online. In 2018, UNM charged \$22-\$40 for reserved seats with a chair-back. Reserved seating with chair backs at the GON powwow cost $\$ 32.50$ per day. Patrons who had not purchased tickets online or by phone were able to purchase tickets at walk-up window sales points at the powwow as well as the basketball game. The cost to attend the events was quite similar.

Parking fees were charged for patrons of UNM Basketball games as well as the GON Powwow. Parking for the Lobo game was $\$ 10$. Parking for the GON at Tingley Coliseum was $\$ 10$.

\subsection{Seating}

Arenas, stadia and concert halls are built as venues in which spectacles can be held. Both the GON powwow and UNM basketball game were held in arenas with large seating capacities. Each venue was comfortable and clean. Seating provided good line of site for the powwow and the basketball game respectively.

Numerous event staff were observed at the powwow and basketball game. Upon approaching both venues, parking staff collected fees and directed drivers to parking spots. Staff were observed selling tickets in the kiosks at the GON powwow and box office for the Lobo games. Staff scanned tickets for verification before entry was granted. Security staff were noticed in the parking lot, at points of entry, and inside the venues. Ushers checked ticket assignments and escorted and/or directed patrons to their assigned seats. Concessionaires, and merchandise sales staff were noted on the way to purchased seats. Event staff, including public address announcers, were observed at tables on the south end of the arenas during the powwows and the east end of the arena at the basketball game.

\subsection{Security}

Security appeared to be important at both venues. Screening for powwow patrons was more thorough. In addition to bag checks, screenings were conducted with metal-detecting wands at the entrance to the fairgrounds. Professional-grade cameras and telephoto lenses were prohibited. Spectators entering the Pit for the basketball game were subjected to security screening, which included only a bag check to prevent prohibited items including food, drink, camera lenses longer than six inches, and weapons from being taken into the arenas. In both settings, security staff were visible and seemed to be adequate in numbers considering the flow of pedestrian traffic that moved quickly through the security checkpoints. No waiting was required at either venue. Uniformed security officers were stationed and were highly visible throughout each venue.

\subsection{Program}

Programs were sold at the GON Powwow and the Lobos basketball game. They included current information about the powwow or team, history of the powwow or team, information about participants and organizers, printed sponsor advertisements, and sponsor logos. Program sales produced income for the event organizers and enhanced the experience of the patrons by providing information germane to each event. High school students sold powwow programs. The Lobo programs were sold at an area adjacent to the main entry from behind a counter. The means of program distribution differed in the two settings and the emphasis upon program sales was greater 
Aicinena, S., \& Ziyanak, S. (2019). Examining the Gathering of Nations Powwow and a NCCA Division I basketball game. Journal of Human Sciences, 16(3), 875-884. doi:10.14687/jhs.v16i3.5742

at the powwow. First author was pressured more to purchase a program at the powwow and had to ask staff at the basketball game where one could be purchased.

Sponsor signage was significantly greater at the Lobo game that it was at the powwow. Sponsors' logos were featured on the full-color digital videoboard strip surrounding the inside of the facility. At any given time only one sponsor appeared. All fans would have ample opportunity to see the sponsors as they looked at the scoreboard or in any direction throughout the facility. Forty-six sponsors appeared on the video strip on a rotating basis starting before the time of first author's arrival (one hour before game time) until departure, fifteen minutes following conclusion of the game. Sponsor logos also branded the standards supporting the basketball goals.

Powwow sponsors did not have sponsor signage visible inside Tingley Coliseum during the powwow that could be observed by patrons. Branding was observed inside the arena, but the signs were permanent, not hung by the powwow administrators. Presumably, sponsors paid for their advertisements to be placed inside the Coliseum for a period of time and exclusivity may have been part of the agreement. Powwow sponsor signage was visible inside of Tingley Coliseum's vestibule. Three sponsors had tables at which they distributed information and promotional gifts. Logos were prominently displayed. Signage acknowledging powwow sponsors were also visible throughout the food court and outside the craft sales areas.

Sponsors advertisements were displayed on the powwow programs and Lobos game. The powwow program included sixty-three advertisements not placed by the powwow itself while the Lobos basketball program included eighty-three.

Major corporations deemed both spectacles worthy of sponsorship. UNM Athletics sponsors included Blue Cross-Blue Shield, Nike, Coors, Albertsons, Wells Fargo, and others. GON Powwow sponsors included Facebook, Wells Fargo, Bank of America, Whataburger, Marriott, Ultra Health, Southwest Airlines and others. Sponsors also had a presence on the GON and Lobos websites.

\subsection{Public Address System}

At the Pit and Tingley Coliseum, public address systems that included massive speakers and powerful amplification equipment were used to make announcements and play music. Large venues require such systems to ensure information and music can be heard by all patrons and participants.

First researcher measured the noise level at Tingley Coliseum using the dB Meter Pro app. The average of fourteen readings taken was $101 \mathrm{~dB}$ with the high being $110 \mathrm{~dB}$. The noise level was consistently high at the powwow and the announcer often asked for the decibel level to be turned up. On one occasion, first researcher experienced pain. During the Lobo game, the ambient decibel level was 79 . Twelve measurements were taken immediately after interesting play for which the crowd demonstrated excitement. The average of the twelve measurements was $93.33 \mathrm{Db}$. Though both environments were loud, the powwow was typically louder at any given time. High decibel levels, upbeat music, powwow songs, and announcements added to the ambiance of the spectacles and helped make them bigger than life experiences.

\subsection{Announcer}

Both the powwow and intercollegiate basketball game included formalized entrances onto the arena floor. Announcers and the crowd conveyed excitement as the powwow grand entries took place and over three thousand dancers filled the arena floor. Likewise, when the Lobos entered the arena floor before the start of the game, there was considerable hype, hoopla, and cheering. Introductions and announcements were made before, during and after completion of the powwow events. The powwow announcer introduced the head male dancer, head female dancer, eagle staff bearer, tribal groups, dignitaries and others. Age groups, dance types, and the tribal affiliation of various performers were also announced. At the basketball game, the public-address announcer introduced 

game. Journal of Human Sciences, 16(3), 875-884. doi:10.14687/jhs.v16i3.5742

starters and coaches, as were substitutes and those charged with fouls or shooting free throws. Announcements were also made before, during and after the game.

Veterans and military personnel were honored and thanked for their service to the country over the public address system during the opening ceremonies for the powwow. Several times during each powwow session, veterans were thanked for their service by the emcee. Notably, Native Americans serve in the military at a higher per capita rate than any other ethnic group (Gover, 2015; Naval History, 2017; WTOP, 2017).

\subsection{American flag}

According to Flynn (2016), "From a non-Aboriginal perspective, the eagle staff can be compared to a national flag: it represents people, states, governments, regiments and battle honours. Thus, it is an honoured and sacred symbol" (p. 3). The words to a Kiowa flag song, translated into English, may serve as an example of a flag song, "United States of America, and the country I love. I am courageous. United States of America, its staff will always remain standing forever 'til the end of the world" (Heth and Vennum 1997, p. 13).

At the basketball game, the announcer asked the crowd to honor the American flag as it was carried on to the floor by military honor guards before the playing of the National Anthem. The American flag was not visible during GON Powwow opening ceremonies nor was the National Anthem sung. At each powwow session, the eagle staff was carried into the powwow circle as a flag song was performed.

\subsection{Entertainment}

Before each session of the GON Powwow, Native American performers provided musical entertainment. Ancillary to the powwow circle, the GON presented live performances throughout the day and evening on "Stage 49", located outside the main venue. Activities peripheral to the main activities, powwow, and game, added to the interest and perceived importance of the cultural events. Before basketball games, during breaks, and after games, entertainment was provided through the playing of popular music over the PA system. The UNM pep band, cheer, and dance squads also provided entertainment in conjunction with the basketball games.

Huge videoboards were used to show live play/dancing and replays, in addition to ancillary entertainment and promotional activities during both the powwow and basketball game. They were located on the northern and southern end of each facility. The live stream and video-replays enhanced the spectator experience and assisted in making each event larger than life.

\subsection{Competition}

At the GON powwow, dancers, singers, and drum groups competed for prize money. In 2018, $\$ 200,000$ in cash prizes was awarded in five singing and drum categories and thirty-seven dance categories. Competition is a component of collegiate athletic contests, including basketball games played by the UNM Lobos. Winners and losers are determined, and results are made public by the local media. Both basketball players and dancers wore numbers as they competed. Competition occurred at the powwow and Lobo game.

Neither GON Powwow dancers nor the basketball players were responsible for officiating or judging their own events. Basketball officials made sure that published NCAA men's basketball rules were followed. Eleven powwow judges were responsible for selecting winners in dance competitions based upon traditional criteria applicable to performance of the dance, including how each dancer's regalia's beadwork, and handcrafting contributed to the overall impression of the performance (Gathering of Nations, 2018b). There were also judges for the drum and singing competitions. Table staff were present at basketball games as well as the powwows. Table staff attend to statistics, scoring, announcements, and related activity associated with staging of the event. 
Aicinena, S., \& Ziyanak, S. (2019). Examining the Gathering of Nations Powwow and a NCCA Division I basketball game. Journal of Human Sciences, 16(3), 875-884. doi:10.14687/jhs.v16i3.5742

\subsection{Concession and Merchandise Sales}

Vendors at the basketball game and powwow sold concessions. During the powwow, food was sold in the food court outside Tingley Coliseum by numerous vendors. Hot dogs, hamburgers, potato chips, French fries, nachos, and other typical American sports venue concessions were available. In addition, traditional native foods were offered for sale including fry bread, Navajo burgers, mutton stew, kneel-down bread and others. The variety of concessions was superior at the powwows, however, having to purchase them outside the coliseum was an inconvenience.

Inside the Pit, twenty-five different varieties of food and beverage types were sold at the Lobo games. Beer was sold at the Lobo game, but not at the powwow.

Typical souvenir items such as hats, t-shirts, sweatshirts, bumper stickers, key chains and various other items were sold at the powwow's Indian Trader's Market adjacent to Tingley Coliseum. Attendees could also select from hundreds of traditional native arts and crafts such as dreamcatchers, sand paintings, handmade Native American jewelry, ribbon shirts, shawls, and blankets. Over 800 Native craftsmen sold items at the 2018 Indian Traders Market. The number and variety of vendors and objects available for sale was vastly superior at the powwow. At the basketball game, merchandise including t-shirts, sweatshirts, key chains, mugs, stadium chairs, blankets, football, basketballs, foam hands, flags, stuffed animals, koozies, decals, pom-poms, and stadium cushions and various other items were sold the Lobo Den, a store encompassing approximately 1500 square feet.

\section{Discussion}

By the end of World War II, powwows had become secularized. Over time, many Native Americans accepted the idea of payment for performance of cultural activities. Competition is ubiquitous in America. Many Native Americans have accepted competitive sport as reflected in participation in organized youth sport and high school athletic programs. Further, events such as Native American basketball and softball contests are commonly held and promoted on internet sites. All-Indian National Championships are conducted in the sports of basketball, softball, boxing and rodeo.

That some Native Americans would compete in dance contests should come as no surprise. Doing so would be an indication that, though traditions of dance have been maintained, a desire to compete has been adopted by the competitive dancers. The opportunity to earn income through dance competitions would also be a factor driving competitive dancers to compete in LICPs.

Our findings demonstrate that the GON Powwow and UNM Lobos basketball games both possess the characteristics of spectacles. Each is a large-scale, extravagant cultural production that is replete with striking visual imagery and dramatic action that is watched by mass audiences. LICPs and NCAA basketball games are rightly considered spectacles.

LICPs serve as a site at which Native Americans celebrate shared Pan-Indian culture. As the events involve members of numerous tribes from all over North America, they are understandably large. The fact that they are commercialized assists in drawing both competitors and spectators, contributing to the grandness of the events.

Finally, the promotional and structural characteristics of the GON Powwow and New Mexico Lobos basketball game from advertising to staging each spectacle were compared. As mentioned in the findings, we found that twelve factors are important to the advertising and staging of the GON Powwow and NCAA Division I men's basketball games. 
Aicinena, S., \& Ziyanak, S. (2019). Examining the Gathering of Nations Powwow and a NCCA Division I basketball game. Journal of Human Sciences, 16(3), 875-884. doi:10.14687/jhs.v16i3.5742

\section{Conclusion}

NCAA Division I basketball is characterized as a commercial enterprise. Millions of dollars are invested in the programs to support coaching staffs, facilities, scholarships and general operations. A commercial emphasis upon the generation of income is vital. On the other side, powwows as traditional Native American cultural events were neither public, nor commercial in nature. When the first author attended his first Gathering of Nations Powwow, he was quite shocked by the apparent similarities between commercialized NCAA Division I basketball games held at UNM's PIT and the powwow that was held in the same venue.

Though pre-game activities were observed in both the powwow and basketball game, there were differences noted concerning the national anthem. Before basketball games, the United States Flag was displayed, and the national anthem was performed. The eagle staff was exhibited, and drum/singing groups performed a flag song during powwow opening ceremonies. In their way, Native Americans honored country through the eagle staff and flag song.

Differences were also noted in the number and variety of food, beverage, and merchandise items for sale at the events. A greater number of concession and merchandise vendors were present at the powwow. The variety of food and the selection of merchandise items available were overwhelmingly superior to those available at the basketball game.

The GON Powwow shared the structural characteristics of the UNM Lobos basketball game. Both were spectacles. If contest powwow dancing could be properly classified as a sport, large intertribal contest powwows would rightfully be considered a spectator sport.

\section{References}

Abdul-Karim, A. (2015). Annual powwow to be held in New Haven's East Rock Park. New Haven Register (CT). Retrieved from https://www.nhregister.com/lifestyle/article/Annualpowwow-to-be-held-in-New-Haven-s-East-11356312.php.

Barker, J. (2010, November 7). Heartbeat of the people. Northwest Florida Daily News (Fort Walton Beach, FL). Retrieved from http://search.ebscohost.com.ezproxy.utpb.edu/login.aspx?direct $=$ true $\& \mathrm{db}=\mathrm{n} 5 \mathrm{~h} \& \mathrm{AN}=2 \mathrm{~W}$ 63743096603\&site $=$ ehost-live.

Cogley, R. (1995). Two approaches to Indian conversion in Puritan New England: The missions of Thomas Mahew Jr. and John Eliot. Historical Journal of Massachusetts, 23 (1): 44-60. http://www.wsc.mass.edu/mhj/pdfs/Cogley\%20combined.pdf

Dell'Angela, T. (2003, June 17). Impresario creates controversy with powwow success. Chicago Tribune. Retrieved from http://articles.chicagotribune.com/2003-0625/features/0306240407_1_first-powwow-tribes-american-indian.

DesJarlait, R. (1997). The contest powwow versus the traditional and the role of the Native American community. Wicazo Sa Review, 12 (1): 115-127.

Dufrene, P. (1990). Exploring Native American Symbolism. Journal of Multi-Cultural and Cross-Cultural Research in Art Education, 8 (1): 38-50.

Eisen, G. (1978). Games and sporting diversions of the North American Indians as reflected in American historical writings of the sixteenth and seventeenth centuries. Canadian Journal of History of Sport and Physical Education, 9(1), 58-85.

Ellis, C., Lassiter, L. E., \& Dunham, G. H. (2005). Ponnow. Lincoln: University of Nebraska Press.

Eschbach, K., \& Applbaum, K. (2000). Who goes to powwows? Evidence from the survey of American Indians and Alaska Natives. American Indian Culture and Research Journal, 24(2), 6583. 
Aicinena, S., \& Ziyanak, S. (2019). Examining the Gathering of Nations Powwow and a NCCA Division I basketball game. Journal of Human Sciences, 16(3), 875-884. doi:10.14687/jhs.v16i3.5742

Flynn, N. (2016). The sacred tradition of the eagle staff. Canadian Army. Retrieved from http://www.army-armee.forces.gc.ca/en/news-publications/national-news-details-nomenu.page?doc $=$ the-sacred-tradition-of-the-eagle-staff/iaiir9qg.

Fowler, L. (2005). Local contexts of pownow ritual. In Pownow, edited by Clyde Ellis, Luke Lassiter and Gary Dunham, 68-82. Lincoln: University of Nebraska Press.

Gathering of Nations. (2018a). Gathering of nations powwow. Retrieved from http://www.gatheringofnations.com/powwow.aspx.

Gathering of Nations. (2018b). Gathering of nations powwow program. Albuquerque: Gathering of Nations. Retrieved from http://www.gatheringofnations.com/powwow.aspx.

Golobos.com. (2019). University of New Mexico lobos athletic website. Retrieved from https://golobos.com/index.aspx?path=mbball.

Gover, K. (2015, May 22). American Indians serve in the U.S. military in greater numbers than any ethnic group and have since the revolution. Huffington Post. Retrieved from https://www.huffingtonpost.com/national-museum-of-the-american-indian/americanindians-serve-in-the-us-military_b_7417854.html.

Harper, D. (2018). Powwow. Etymonline. Retrieved from https://www.etymonline.com/word/powwow.

Heth, C., \& Vennum, T. (1997). American warriors: songs for veterans. Salem, MA: RYKO Records. Retrieved from https://media.smithsonianfolkways.org/liner_notes/hart/HRT15014.pdf.

Hoefnagels, A. (2007). The dynamism and transformation of tradition: factors affecting the development of powwows in Southwestern Ontario. The Free Library. Retrieved from https://www.thefreelibrary.com/The dynamism and transformation of "tradition": factors affecting the-a0179133363.

Manning, F. (1992). Spectacle." In folklore, cultural performances, and popular entertainments, edited by Richard Bauman, 291-299. New York: Oxford University Press.

McClaskey, M. (2009). Your guide to understanding and enjoying powwows. Montana: opi.mt.gov Indian Education Division. Retrieved 11/1/2018 from https://opi.mt.gov/Portals/182/Page\%20Files/Indian\%20Education/Indian\%20Educatio n\%20101/PowWows.pdf

McDermott, J. (2012). Mashantuckets host 20th annual Schemitzun powwow. Day, The (New London, $\quad$ CT). Retrieved from http:/ / search.ebscohost.com.ezproxy.utpb.edu/login.aspx?direct $=$ true\&db $=\mathrm{n} 5 \mathrm{~h} \& \mathrm{AN}=2 \mathrm{~W}$ 63647158498\&site $=$ ehost-live.

Metsker, M. (2013). Bridging cultural gaps. Moscow-Pullman Daily News. 4/1/2013. Retrieved fromhttp:// search.ebscohost.com.ezproxy.utpb.edu/login.aspx?direct $=$ true $\& \mathrm{db}=\mathrm{n} 5 \mathrm{~h} \& \mathrm{AN}$ $=2 \mathrm{~W} 6371308606 \&$ site $=$ ehost-live.

Naval History, (2017). 20th century warriors: Native American participation in the U.S. Military. Naval History. Retrieved from https://www.history.navy.mil/research/library/online-readingroom/title-list-alphabetically/t/american-indians-us-military.html.

NCAA, (2018). NCAA men's basketball attendance: All divisions. NCAA.org. Retrieved from http://fs.ncaa.org/Docs/stats/m_basketball_RB/Reports/attend/2017.pdf.

Shepard, T. (1648). The clear sunshine of the Gospel breaking forth upon the Indians in New England. London: R. Cotes. (Reprinted in 1865 New York: Joseph Sabin). Retrieved from https://archive.org/details/clearsunshineofg00sheprich.

WTOP, (2017). In Indian country, honoring flag might mean different anthem. Associated Press. Retrieved from https://wtop.com/national/2017/11/in-indian-country-honoring-flagmight-mean-different-anthem/slide/1/.

Ziyanak, S. (2014).New emerging Ahiskan Turk ethnic identity in the United States. International Journal of Human Sciences, 11(1), 688-699. 